\title{
ASEAN-CANADA FREE TRADE AGREEMENT: POTENTIAL ECONOMIC FOR ASEAN MEMBER COUNTRIES
}

\author{
Indanazulfa Qurrota A'yun \\ Universitas Ahmad Dahlan \\ e-mail: indanazulfa.a’yun@ep.uad.ac.id
}

\begin{abstract}
ASEAN and Canada agreed to establish cooperation as ASEAN-Canada Free Trade Agreement (FTA). This cooperation aims to strengthen economic relations between ASEAN and Canada by eliminating tariff barriers for almost all of trade in goods. Therefore, this study aims to calculate how big the effect of the ASEAN-Canada FTA trade agreement on the macroeconomic conditions of ASEAN member countries. The analysis method used is Computable General Equilibrium (CGE) model using Global Trade Analysis Project (GTAP) version 9A. This cooperation is expected to reduce trade barriers in all sectors, particularly tariff reductions as a representation of declining trade barriers in both ASEAN and Canada. This study analyse two trade policy scenarios by $50 \%$ and $100 \%$ (full liberalization) tariff reduction. The simulation results show that all ASEAN member countries get the benefit from full liberalization or a 50\% tariff reduction on welfare except Laos and Philippines. In addition, this cooperation also can increase the real GDP in all ASEAN member countries and trade balance for Indonesia, Philippines, Singapore, Myanmar and Canada. It also has negative impacts on inflation and investment for some ASEAN member countries such as Brunei Darussalam, Cambodia, Laos, Malaysia and Thailand.
\end{abstract}

Keywords: ASEAN-Canada FTA, CGE Model, GTAP, Macroeconomics, Trade

\section{INTRODUCTION}

The globalization era demands the greater economic openness of every country in the world, both in trade and the financial sector. This is marked by the increasing number of economic cooperation that is formed (Sachitra, 2000). Economic openness illustrates the increasing absence of barriers in trading, both tariff and non-tariff, as well as the smooth movement of capital mobility between countries. In theory, economic openness promises benefits for all the countries involved. Advantages of international trade include opening up broader market access, achieving higher levels of efficiency and economic competitiveness, as well as greater employment opportunities (Salvatore, 2012).
Trade openness is now regarded as one of the main tools to boost economic growth and achieve maximum benefit from its comparative advantage (Jadoon et al., 2015). In addition, trade liberalization will encourage the expansion of world trade growth towards the output shown by exports and imports (Baldwin, 2003). This is in line with Wyatt and Walter (1996) which explains that the existence of economic regionalism is the process of policy implementation by a group of countries in a particular region with the aim of increasing the volume of goods and services exchange and production factors between countries. Other objectives of economic regionalism in the field of trade include the reduction or elimination of trade barriers in the form of tariffs and non-tariffs in the form of Free Trade Agreements (FTA) or 


\section{JURNAL OPTIMUM, Volume 10, Nomor 1 Maret 2020}

Preferential Trade Agreements (PTA) (Boween et al., 2001). In general, regionalism has a positive impact on welfare level, trade volume, macroeconomics and encourage the industrialization that can become the engine of economic growth in each country.

Free Trade Agreements (FTA) constitute a free trade agreement undertaken by a country against another country. According to Okabe (2014), the FTA can improve market access in improving international trade flows and driving bilateral and multilateral trade relations. In addition, the FTA will also have a positive effect in terms of increasing welfare, trade intensity and trade balance for member countries (Winham, 2003). Thus the opinion of Hertel et al. (2001) that the FTA in bilateral trade will increase investment, capital accumulation and significant economic growth in Singapore and Japan.

The form of international trade relations in the form of FTA has been widely implemented by ASEAN countries to major trading partner countries. One of the new cooperation frameworks that will be implemented in ASEAN after the 8th Meeting of Senior Economic Officials Meetings (SEOM) on 30 June 2016 in Laos is the ASEAN Free Trade Agreements (FTA) with Canada. After the meeting, ASEAN-Canada committed a feasibility study for the framework of ASEAN-Canada Free Trade Agreements. The first step taken is to conduct a video conference between Indonesia as a country coordinator with the Canadian side. Video conferencing has been conducted twice on October 5, 2016 and January 13, 2017. The last video conference result agreed to do Joint Feasibility Study (JFS) to be undertaken by third parties with the scope of JFS covering ASEAN (as a whole) and Canada.

The objective of the FTA framework is a means to increase market access and strengthen domestic trade and prosperity flows (Dixon and Rimmer, 2010). This bilateral and regional trade deal benefits greatly when the parties are ready to move faster and liberalize more deeply than what has been achieved (Lloyd and Maclaren, 2004 and Lloyd, 2010). The positive impact of ASEAN-Canada FTA trade cooperation is also demonstrated by Woo (2005). By using Computable General Equlibrium (CGE), ASEAN-Canada FTA cooperation is predicted to provide positive benefits for all member countries. However, the magnitude of the impact is not predictable. Canadian exports to ASEAN are predicted to increase by 16.6 percent and Canadian imports from ASEAN countries are also expected to increase by 21 percent. Sectors in Canada with significant export increases include wheat, chemicals, rubber and plastics, industrial and paper machinery. Meanwhile, Canada is predicted to experience significant import increases in the apparel sector, leather and textile products. The positive estimation results of the ASEAN-Canada FTA shown by some of the above studies, becomes the basic argument of Barichello and Yap (2010) in emphasizing the importance of a comprehensive analysis of the feasibility of the ASEAN-Canada FTA or the comprehensive economic partnership agreement between the two parties.

The ASEAN-Canada Free Trade Agreements are an external stimulus to reform the economic conditions of ASEAN countries, especially for the improvement of competitiveness, as currently (in 2011) Indonesia's export contribution to GDP is only $20 \%$, Malaysia $(79.3 \%)$, Thailand $(66.2 \%)$ and Singapore $(157.6 \%)$ as well as greater market access opportunities. Based on data obtained from Trade Map during the period 2012-2016, table 1.1 below shows that in general the majority of ASEAN member countries have experienced trade surplus with Canada. In contrast, Indonesia, Brunei Darussalam, Singapore and Myanmar still experienced trade deficits in some periods. Malaysia, Laos and the Philippines show a decline in the last two periods in its export activities against Canada. While Cambodia 
and Vietnam are two ASEAN member countries whose trade performance has increased significantly from both the total trade indicator and the trade balance.

Table 1.1

\section{The ASEAN-Canadian Trade Balance of} the Year 2012-2016 (Thousand USD)

\begin{tabular}{|rlrrrrr|}
\hline No & Country & $\mathbf{2 0 1 2}$ & $\mathbf{2 0 1 3}$ & $\mathbf{2 0 1 4}$ & $\mathbf{2 0 1 5}$ & $\mathbf{2 0 1 6}$ \\
\hline 1 & Cambodia & 388,714 & 453,33 & 495,714 & 520,277 & 604,961 \\
\hline 2 & Brunei & 11,354 & $-7,3$ & 209,972 & $-4,758$ & $-10,162$ \\
\hline 3 & Malaysia & 17,898 & $-199,201$ & $-112,102$ & 88,754 & 37,889 \\
\hline 4 & Singapura & $-48,371$ & 385,583 & $-203,292$ & $-359,952$ & $-519,702$ \\
\hline 5 & Indonesia & $-1,018,300$ & $-1,285,124$ & $-1,105,177$ & $-886,907$ & $-650,458$ \\
\hline 6 & Laos & $-8,878$ & 9,25 & 10,898 & 13,09 & 8,188 \\
\hline 7 & Vietnam & 700,774 & $1,151,439$ & $1,692,503$ & $1,959,313$ & $2,257,076$ \\
\hline 8 & Myanmar & $-3,311$ & $-3,664$ & $-6,484$ & $-2,312$ & 6,695 \\
\hline 9 & Thailand & 645,718 & 485,399 & 559,362 & 418,997 & 424,58 \\
\hline 10 & Philipines & 175,731 & 39,153 & 261,452 & 169,307 & 105,918 \\
\hline
\end{tabular}

Source: Trade Map, 2018

In 2016, based on data obtained from the Trade Map that the total export value of ASEAN to Canada reached USD 8,479,757 thousand, where the products exported include telephones (HS 851712), ignition wiring sets (HS 854430), frozen shrimps ( HS 030617), sports wear (HS 640411) and prepared or preserved shoots (HS 160414). While the total import value of ASEAN from Canada is USD 5.125.671 thousand, where the imported products are potassium chloride (HS 310420), wheat (HS 100199), semi-bleached or bleached coniferous chemical wood pulp sulphate (HS 470321) parts of turbojets (HS 841191), and chemical wood pulp (HS 470200).

Based on this background so that the ASEAN-Canada FTA is a long-term goal for both parties to strengthen economic relations both in the public and private sectors which aims to eliminate tariff barriers in almost all trade in goods in order to build inter-regional trade countries participating in the ASEANCanada FTA. The problem to be answered in this research is how the benefit and economic potency for ASEAN member country in
ASEAN-Canada FTA is. It is expected that the ASEAN-Canada FTA can expand the market of ASEAN products to the Canadian market.

\section{LITERATURE REVIEW}

International trade can be defined as trade transactions of goods and services between the subjects of one country's economy with the economic subject of another country. The economic subjects are residents consisting of ordinary citizens, export companies, import companies, industrial companies or state enterprises. International trade occurs due to differences in the potential of natural resources, capital resources, human resources and technological advancement between countries (Halwani 2005). Every country that trades aims to profit from that trade. In addition to profit-seeking motives, Krugman (1991) reveals that the main reasons for international trade are (1) Countries are trading because they differ from each other (2) Countries are trading with the aim of achieving economic scale.

Theoretically, a country in state 1 will export commodity $\mathrm{X}$ to another country, but in state 2 domestic price of country 1 is relatively lower than domestic price of country 2 (Figure 1.1). Price structure that occurs in country 1 is lower because domestic production is greater than its domestic consumption resulting in excess supply in country 1 . On the other hand, in country 2 excess demand occurs because the domestic consumption is greater than the domestic production so that the price in the country 2 higher. Thus, state 1 has the opportunity to sell its excess production to another country, while country 2 wishes to buy commodity X from another relatively cheaper country. If there is communication between country 1 and country 2, then there will be trade between both with the same price in both countries. 
Figure 1.1

Partial Trade Balance Analysis International (Salvatore, 2012)

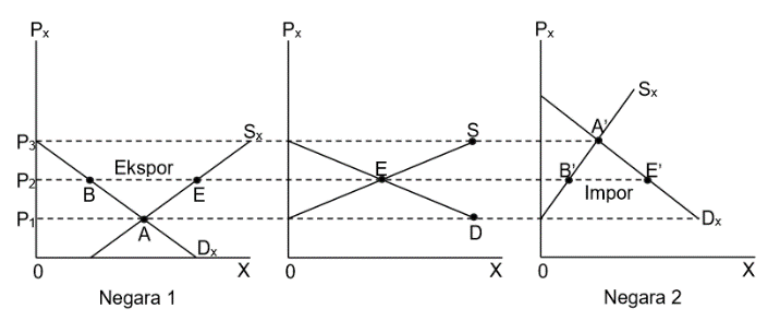

Figure 1.1 shows that before international trade the price in country 1 is $\mathrm{P} 1$, while the price in country 2 is P3. Offers in international markets occur when international prices are higher than $\mathrm{P} 1$, whereas demand in international markets occurs when international prices are lower than P3. With international trade, country 1 will export commodity $\mathrm{X}$ for $\mathrm{BE}$, while state 2 will import $\mathrm{X}$ commodity equal to $\mathrm{B}$ 'E 'at international price level (P2).

The concept of free trade was first introduced by Adam Smith in the early 19th century with absolute comparative theory. Adam Smith's theory was later perfected by David Ricardo (1817) with a model of comparative advantage (The Theory of Comparative Advantage). In contrast to the concept of absolute advantage that emphasizes lower real costs, comparative advantage is more concerned with the relative price difference between the two inputs of production as a determinant of trade. According to David Ricardo (Hady, 2001), trade can be done by a country that does not have an absolute advantage in both traded commodities by specializing in products with less absolute losses or comparative advantages. This is known as the Law of Comparative Advantage.

Ricardo's classical theory was further developed by Heckscher-Ohlin (H-O) with The Theory of Factor Proportions (19491977). The H-O model says that although the same level of technology is shared, international trade will still occur when there is a difference in factor-endowment between each country. One country with excessive capital ownership will specialize and export capital-intensive goods, and vice versa a country with excessive labor ownership will produce and export labor-intensive goods. According to the H-O theory, a country will produce and export goods using abundant production factors, and importing goods for which production is needed is rarely available (scarce) in the country.

Furthermore, economic integration is defined as the elimination of discrimination within a region. The theory of economic integration refers to a commercial policy or trade policy that discriminately lowers or removes trade barriers only among the mutually agreed states to establish a limited economic integration (Salvatore, 2007). Economic integration aims to open the widest possible trade access between one country and another. Competition among market participants will lead to lower prices for similar goods and services, thereby improving the quality and multiplying options for consumers in an integrated region. The tendency to increase regional economic and financial integration processes in various parts of the world is basically based on the basic concept that the benefits will be greater than the risks to be faced (Oktaviani et al 2014).

Studies on the impact of ASEANCanada FTA cooperation have not been done so much. Several institutions that have published the results of the analysis of the ASEAN-Canada FTA cooperation are the Center for Strategic and International Studies (CSIS), the Institute of Southeast Asian Studies (ISEAS), the Canada-ASEAN Business Council, and the Economic Research Institute for ASEAN and East Asia (ERIA).

The positive impact of the ASEANCanada FTA trade cooperation is shown by Woo (2005), using Computable General Equlibrium (CGE). ASEAN-Canada FTA 


\section{INDANAZULFA QURROTA A'YUN \\ Asean-Canada Free Trade Agreement: Potential Economic For Asean Member Countries}

cooperation is predicted to provide positive benefits for all member countries. However, the magnitude of the impact is not predictable. Canadian exports to ASEAN are predicted to increase by 16.6 percent and Canadian imports from ASEAN countries are also expected to increase by 21 percent. Sectors in Canada with significant export increases include wheat, chemicals, rubber and plastics, industrial and paper machinery. Meanwhile, Canada is predicted to experience significant import increases in the apparel sector, leather and textile products.

Recent studies on the impact of the ASEAN-Canada FTA were recently published by the Canada-ASEAN Business Council $(\mathrm{CABC})$ in its report entitled "The ASEAN Advantage: Report on the Impact of a CanadaASEAN FTA". The results of the CABC (2017) study indicate a potential increase in bilateral trade of 4.8 to 10.9 billion Canadian dollars. Canada's national output is expected to increase by 1.2 billion Canadian dollars by 2027. Positive benefits are also predicted to be felt by ASEAN with an increase in GDP of 1.8 billion Canadian dollars (the sum of GDP of 10 ASEAN countries). However, the magnitude of the increase in national output will vary among ASEAN countries and depends on the preparedness of the country concerned.

CABC (2017) predicts that the sectors that will receive the largest increase in exports include the chemical, rubber and plastics sectors, and machinery and equipment sectors. On the ASEAN side, the sectors that will benefit the most are the textile and apparel sectors. In addition to these sectors, some other sectors in Canada are predicted to get significant benefits are the processed food sector, poultry sector, processed wood and paper sectors, and the metal sector.

Referring to the two company survey results published by CABC in 2013 and 2016, indicates an increase in optimism from Canadian companies about the business climate in ASEAN. In a recent survey it was shown that 94 percent of Canadian firms surveyed were optimistic about the future of their business in ASEAN (CABC, 2016). Most of the companies surveyed strongly supported the initiation of the ASEANCanada FTA. With regard to the main investment destination countries, Canadian companies are still concentrated in relatively advanced ASEAN countries, such as Singapore, Indonesia, Malaysia, Vietnam, Philippines and Thailand (CABC, 2013).

In the feasibility study undertaken by ERIA on the ASEAN-Canada FTA, analyzing 4 (four) simulations using the CGE model, ie (i) the tariff reduction scenario is performed on all products; (ii) the tariff reduction is $100 \%$; (iii) there is a simulation of NTMs decline; (iv) there is a simulated increase in trade facilitation. Given that ERIA's simulation is a reduction in tariffs on all products, it is perfectly reasonable that the positive impacts presented in the ERIA study look great $(2.08$ billion USD in real GDP or equivalent to $0.09 \%$ ).

The simulation results for the NTMs scenario and trade facilitation in the ERIA study look more attractive to both parties. ASEAN is expected to receive a real GDP increase of up to $1.95 \%$ in the NTMs scenario and $5.31 \%$ in the trade facilititation scenario. However, it is important to note that the assumptions used are very strong, ie $10 \%$ NTMs decrease and logistic trade improvement of $20 \%$. In addition, the magnitude of its impact on real GDP is enormous. When compared to the three scenarios in the ERIA study, the conclusion is that tariff reductions do not mean anything to an increase in real GDP. The focus of cooperation is better directed to the improvement of logistics or other trade facilitation between the two parties.

The estimation results show that the impact on exports is very large, reaching $20 \%$ increase in exports to ASEAN and almost $15 \%$ for Canadian exports. In addition, when compared between scenarios, the results show 
that NTMs scenarios and trade facilitation scenarios do not have a major impact on export growth. Taking into consideration the impact on real GDP, there is an indication that the real increase in GDP in the NTMs scenario and the trade facilitation scenario is not due to increased trade but because of the impact on prices.

\section{RESEARCH METHODOLOGY \\ Data}

To see the benefits of a new framework agreement between ASEAN and Canada against ASEAN member countries, this research utilizes secondary data. The data used are obtained from national and international institutions, namely Trademap, UN Comtrade and Worldbank. The main data that is processed in this research using data of GTAP (Global Trade Analysis Project).

The GTAP data is the data covering the input-output tables in each country and the flow of inter-state trade with many commodities. The GTAP data used in this study is GTAP Database version 9A published in 2015. GTAP version 9A is updated in terms of data using reference data for 2004, 2007 and 2011 and comprises 140 regions and 57 sectors.

\section{Analysis Method}

The analytical method used in this research is using 9A version of Computable General Equilibrium (CGE) of Global Trade Analysis Project (GTAP) used to see the impact of the ASEAN-Canada cooperation framework on economic and sectoral potential in ASEAN member countries. This study conducted two simulations simulated by cutting $50 \%$ tariff and elimination of $100 \%$ tariff (full liberalization) for all commodities between ASEAN and Canada. The selection of CGE models in this analysis is due to the purpose of this study is to calculate how much profit is gained on the enactment of the ASEAN-Canada FTA Agreement on the economic potentials obtained when the entry into force of the ASEAN-Canada FTA or in other words ex-ante analysis.

There are several empirical studies that calculate the impact (FTA) and its members in terms of macroeconomic and sectoral. Zhou et.al (2010) uses a GTAP analysis tool to see the impact of the ASEAN-China FTA (ACFTA) FTA on trade, exports and imports, and GDP. The results of the implementation of ACFTA will have a significant impact on trade, production and GDP of ACFTA members either bilaterally and with other member countries.

Other researches, Caliendo, Lorenzo and Parro, Fernando (2014) in his paper on the impact of tariff reductions in NAFTA on the trade and welfare of its members, said that the impact of tariff reductions would increase welfare in Mexico by $1.31 \%$, USA by $0.08 \%$ and Canada decreased by $0.06 \%$.

Furthermore, for this study, state aggregation was conducted into 11 groups in GTAP version 9A as presented in Table 3.1.

Table 3.1

Agregasi Negara untuk Skema FTA ASEANKanada

\begin{tabular}{|c|c|c|c|}
\hline No. & Code & Name & explanation \\
\hline 1. & Indonesia & Indonesia & Indonesia \\
\hline 1. & Malaysia & Malaysia & Malaysia \\
\hline 2. & Singapore & Singapore & Singapore \\
\hline 4. & Thailand & Thailand & Thailand \\
\hline 5. & Vietnam & Vietnam & Vietnam \\
\hline 6. & Brunei & Brunei & Brunei \\
\hline 7. & Cambodia & Cambodia & Cambodia \\
\hline 8. & Philippines & Philippines & Philippines \\
\hline 9. & Myanmar & Myanmar & Myanmar \\
\hline 10. & $\begin{array}{l}\text { Southeast } \\
\text { asia }\end{array}$ & Southeast & Laos \\
\hline 11. & ROW & $\begin{array}{l}\text { Rest of the } \\
\text { world }\end{array}$ & $\begin{array}{lr}\text { China; } & \text { Korsel; } \\
\text { Australia; } & \text { New } \\
\text { Zealand; } & \text { Rest of } \\
\text { Oceania; } & \text { Hong } \\
\text { Kong; } & \text { Japan; } \\
\text { Taiwan; Rest of East } \\
\text { Asia; Rest } \\
\text { Southeast } & \text { Asia; } \\
\text { Bangladesh; India; } & \text { Sri Lanka; Rest of }\end{array}$ \\
\hline
\end{tabular}




\section{Asean-Canada Free Trade Agreement: Potential Economic For Asean Member Countries}

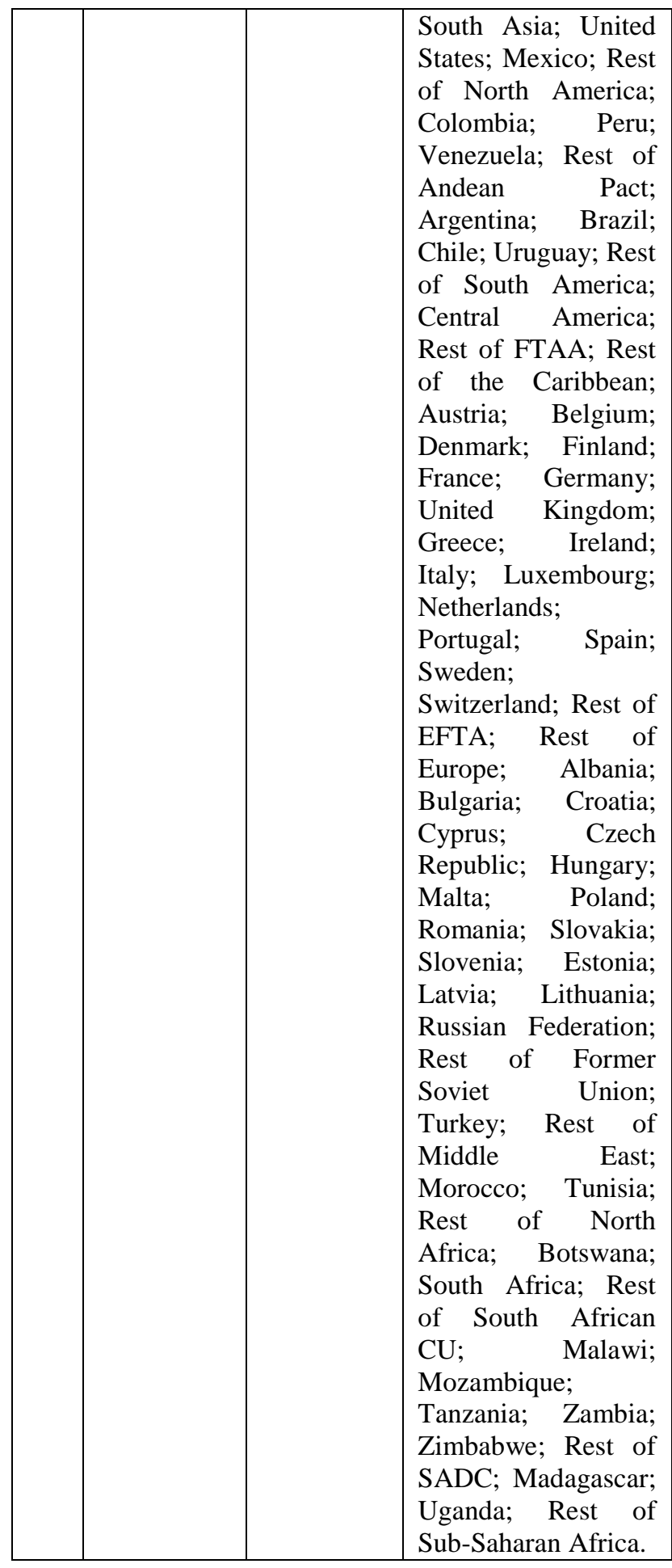

In the sector, aggregation is based on 57 or one to one. It is intended that the results obtained can be explained in detail and clear. While the variables used in this study are referring to (Siriwardana, 2015), where the variables used to view macroeconomic conditions as a result of the existence of trade schemes between ASEAN and Canada are welfare, real gdp, inflation, trade balance and investment.

The framework of ASEAN FTA cooperation with Canada is expected to provide benefits and benefits for ASEAN and Canadian member countries. Therefore, to be able to know how the impact of trading scheme then using data and model of GTAP used some simulation as follows:

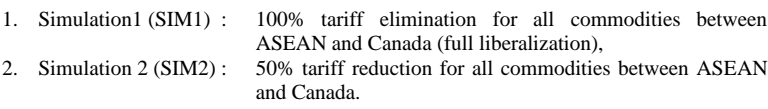
ASEAN and Canada (full liberalization),

2. Simulation 2 (SIM2): $50 \%$ tariff reduction for all commodities between ASEAN and Canada.

\section{RESULT AND DISCUSSION}

\section{Trade Profile of ASEAN Member Countries with Canada}

During the period 2012-2016, in general the majority of ASEAN member countries have experienced trade surplus with Canada. However, for Indonesia, Brunei Darussalam, and Singapore are still experiencing trade deficit. Especially Indonesia which always deficit in every year from year 2012-2016. While Cambodia and Vietnam are two ASEAN member countries whose trade performance has progressively increased both from total trade indicators and trade balance. Then, the Philippines and Thailand also have good trading performance which always has a surplus although it is still fluctuating from 2012-2016.

In terms of total trade, Indonesia is the country with the largest total trade with Canada compared to other ASEAN countries, followed by Thailand, Singapore and Vietnam. Countries that have the smallest trade total with Canada are Myanmar, Laos and Brunei Darussalam. In detail the development of ASEAN and Canadian trade balance can be seen in table 4.1 . 
Table 4.1

General Conditions of Trade of ASEAN Member Countries and Canada in 2012-2016

\begin{tabular}{|c|c|c|c|c|c|}
\hline State & 2012 & 2013 & 2014 & 2015 & 2016 \\
\hline \multicolumn{6}{|l|}{ Cambodia } \\
\hline Trade Balance & 388,714 & 453,33 & 495,714 & 520,277 & 604,961 \\
\hline Total trade & 400,700 & 465,726 & 522,230 & 581,793 & 115,264 \\
\hline \multicolumn{6}{|l|}{ Brunei } \\
\hline Trade Balance & 11,354 & $-7,3$ & 209,972 & $-4,758$ & $-10,162$ \\
\hline Total trade & 13,244 & 1,168 & 247,218 & 6,072 & 11,784 \\
\hline \multicolumn{6}{|l|}{ Malaysia } \\
\hline Trade Balance & 17,898 & $-199,201$ & $-112,102$ & 88,754 & 37,889 \\
\hline Total trade & $1,877,566$ & $1,802,053$ & $1,726,946$ & $1,475,612$ & $1,371,099$ \\
\hline \multicolumn{6}{|l|}{ Singapore } \\
\hline Trade Balance & $-48,371$ & 385,583 & $-203,292$ & $-359,952$ & $-519,702$ \\
\hline Total trade & $2,437,083$ & $2,836,475$ & $2,156,538$ & $1,183,049$ & $2,003,392$ \\
\hline \multicolumn{6}{|l|}{ Indonesia } \\
\hline Trade Balance & $-1,018,300$ & $-1,285,124$ & $-1,105,177$ & $-886,907$ & $-650,458$ \\
\hline Total trade & $2,603,192$ & $2,849,818$ & $2,615,219$ & $2,331,597$ & $2,115,602$ \\
\hline \multicolumn{6}{|l|}{ Laos } \\
\hline Trade Balance & $-8,878$ & 9,25 & 10,898 & 13,09 & 8,188 \\
\hline Total trade & 16,204 & 9,898 & 14,136 & 15,660 & 12,650 \\
\hline \multicolumn{6}{|l|}{ Vietnam } \\
\hline Trade Balance & 700,774 & $1,151,439$ & $1,692,503$ & $1,959,313$ & $2,257,076$ \\
\hline Total trade & $1,612,250$ & $1,964,185$ & $2,462,809$ & $2,855,935$ & $3,048,018$ \\
\hline \multicolumn{6}{|l|}{ Myanmar } \\
\hline Trade Balance & $-3,311$ & $-3,664$ & $-6,484$ & $-2,312$ & 6,695 \\
\hline Total trade & 6,875 & 9,030 & 14,634 & 8,192 & 35,053 \\
\hline \multicolumn{6}{|l|}{ Thailand } \\
\hline Trade Balance & 645,718 & 485,399 & 559,362 & 418,997 & 424,58 \\
\hline Total trade & $2,518,168$ & $2,472,569$ & $2,398,536$ & $2,265,725$ & $2,242,764$ \\
\hline \multicolumn{6}{|l|}{ Philipines } \\
\hline Trade Balance & 175,731 & 39,153 & 261,452 & 169,307 & 105,918 \\
\hline Total trade & 840,639 & 1037,759 & 933,682 & 957,689 & 941,914 \\
\hline
\end{tabular}

Source: Trade Map, 2018.

\section{Macroeconomic Condition of ASEAN Member Countries and Canada}

The population is the market size for an economy. Large market size attracts other countries to invest and trade. Based on Table 4.2 below, Indonesia is the country with the largest population compared to Canada and other ASEAN countries, where in 2016 the population of Indonesia reaches 261 million people. When compared to the previous year in 2015 the number of Indonesian population reached 257 million people, which means there is an increase of about $1 \%$. This reflects Indonesia as a big market for ASEAN and Canadian trading partner countries. After Indonesia, the population most followed by the Philippines, Vietnam and Thailand although the number is not reached 100 million people.

While Canada, in 2016 has a population of 36.2 million people which rose by $0.9 \%$ compared to last year's only 35.8 million people. ASEAN countries that have the smallest population is Brunei Darussalam 0.4 million in the year 2016. The development of the population of ASEAN and Canadian countries in detail can be seen in Table 4.2.

Table 4.2

Macroeconomic Conditions of ASEAN Member Countries and Canada in 2012-2016

\begin{tabular}{|lrrrrr|}
\multicolumn{1}{r}{ Negara } & \multicolumn{5}{c}{ Populasi } \\
\cline { 2 - 6 } & $\mathbf{2 0 1 2}$ & $\mathbf{2 0 1 3}$ & $\mathbf{2 0 1 4}$ & \multicolumn{1}{c|}{$\mathbf{2 0 1 5}$} & \multicolumn{1}{c|}{$\mathbf{2 0 1 6}$} \\
\hline Cambodia & 14.776 .866 & 15.022 .692 & 15.270 .790 & 15.517 .635 & 15.762 .370 \\
\hline Brunei & 399.748 & 405.716 & 411.704 & 417.542 & 423.196 \\
\hline Malaysia & 29.170 .456 & 29.706 .724 & 30.228 .017 & 30.723 .155 & 31.187 .265 \\
\hline Singapore & 5.312 .437 & 5.399 .162 & 5.469 .724 & 5.535 .002 & 5.607 .283 \\
\hline Indonesia & 248.883 .232 & 252.032 .263 & 255.131 .116 & 258.162 .113 & 261.115 .456 \\
\hline Laos & 6.415 .169 & 6.494 .557 & 6.576 .397 & 6.663 .967 & 6.758 .353 \\
\hline Vietnam & 90.451 .881 & 91.497 .725 & 92.544 .915 & 93.571 .567 & 94.569 .072 \\
\hline Myanmar & 50.986 .514 & 51.448 .196 & 51.924 .182 & 52.403 .669 & 52.885 .223 \\
\hline Thailand & 67.843 .979 & 68.143 .065 & 68.416 .772 & 68.657 .600 & 68.863 .514 \\
\hline Philipines & 96.866 .642 & 98.481 .032 & 100.102 .249 & 101.716 .359 & 103.320 .222 \\
\hline ASEAN & 611.106 .924 & 618.631 .132 & 626.075 .866 & 633.368 .609 & 640.491 .954 \\
\hline Canada & 34.750 .545 & 35.152 .370 & 35.535 .348 & 35.832 .513 & 36.264 .604 \\
\hline
\end{tabular}

Source: Worldbank, 2018.

\section{Trade Performance of ASEAN Member Countries with Canada}

In 2017, the total value of ASEAN's exports to Canada reached USD 9.360.965 thousand, where there is a significant increase from the year 2016 amounted to USD $7,387,501$ thousand. While the total value of ASEAN imports from Canada amounted to USD 6,254,965 thousand. This shows that export activities between ASEAN and Canada still dominate over imports. Products exported and imported between ASEAN and Canadian countries are shown in the following table 4.3 and 4.4 , in which the table shows that most are complementary products.

Table 4.3

The Export of ASEAN to Canada for 15 Largest Items in 2015-2017

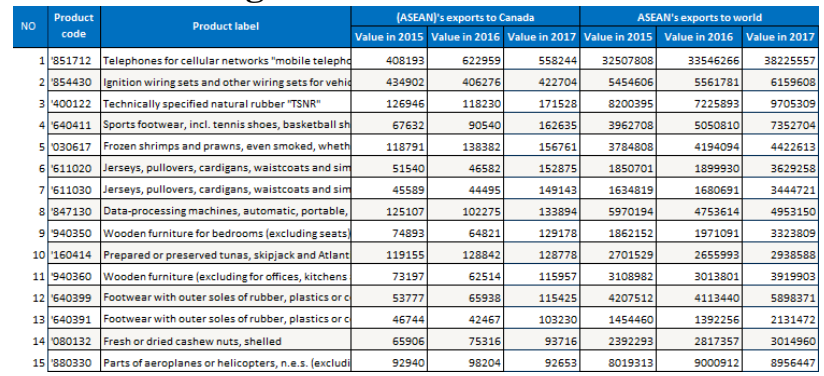

Source: Trade Map, 2018. 
Table 4.4

The Import of ASEAN to Canada for 15 Largest Itemsin 2015-2017

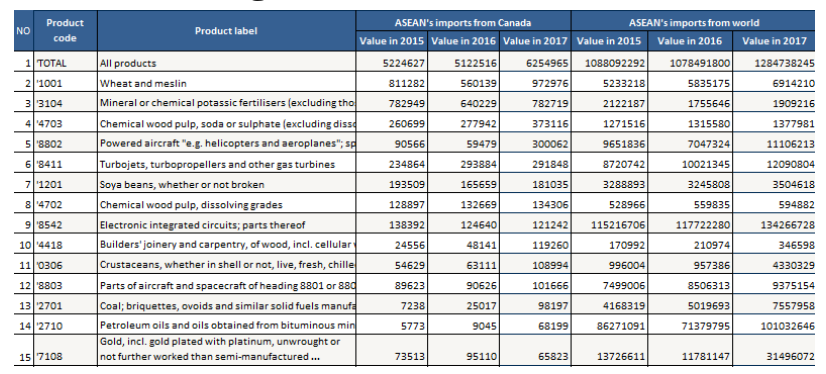

Analysis of Impact of ASEAN-Canada FTA Cooperation on Welfare of ASEAN Member Countries

This study will analyze macroeconomic perspectives in the ASEAN-Canada FTA cooperation scheme on macroeconomic variables such as welfare level (using proxy equivalent variation), output at national level (using real GDP proxies) and inflation rate seen from GDP deflator. On the expenditure side, the components of GDP analyzed are investment spending and trade performance shown through trade balance variables (DTBAL).

Table 4.4 shows the simulated impact on welfare measured by equivalent variation which is the sum of consumer surplus, suplus producer and government surplus in each ASEAN member country and Canada. The table shows that the highest welfare is obtained by Indonesia in the event of full liberalization, where Indonesia will get a welfare increase of USD 6386.9 million. While other countries such as Vietnam, Thailand and Malaysia only get half the prosperity benefit of Indonesia that get amounted to USD 3785.5 million, USD 3545.82 million and USD 3318.88 million. However, the increase in welfare is still relatively slightly larger when compared with a decrease in tariff by $50 \%$.
Tabel 4.5

Impact of ASEAN-Canada FTA on Welfare (Thousand USD)

\begin{tabular}{lrr}
\hline State & SIM 1 & SIM 2 \\
\hline Rest of World & 62079,54 & 38223,23 \\
Brunei & 175,73 & 88,13 \\
Darussalam & & \\
Cambodia & 10,85 & 34,97 \\
Indonesia & 6386,89 & 2579,01 \\
Laos & $-66,24$ & $-22,79$ \\
Malaysia & 3318,88 & 1833,96 \\
Philipina & $-555,90$ & $-277,11$ \\
Singapore & 3153,36 & 1473,27 \\
Thailand & 3545,82 & 1945,19 \\
Vietnam & 3785,48 & 2080,74 \\
Myanmar & 55,07 & 27,24 \\
Canada & 2617,88 & \\
& & 777,86 \\
\hline
\end{tabular}

Source: GTAP 9A data is processed, 2018

Unlike the case with Cambodia that actually get lower welfare if apply full liberalization that is only USD 10.85 million compared with $50 \%$ decrease tariff which actually get bigger increase that is USD 34,97 million. While countries that experience welfare decline when the ASEAN-Canada FTA is Laos and the Philippines. This shows that with the potential and excellent commodity between Laos, Philippines and Canada have not been able to give positive prosperity benefit.

Analysis of Impact of ASEAN-Canada FTA Cooperation on Real GDP of ASEAN Member Countries

Another important macro economic variable to see the impact of the ASEANCanada FTA scheme is GDP. Table 4.6 shows the results of both simulations of real GDP. From these results it can be seen that for all simulations, ASEAN member countries will get a positive real GDP change. Countries that will get the biggest change in both the first and second simulation is Vietnam at $1.34 \%$ (SIM1) and $0.84 \%$ (SIM2). Furthermore, 
followed by Cambodia, Thailand and Malaysia with a large change of $0.92 \%$, $0.69 \%$ and $0.61 \%$ in case of full liberalization.

Meanwhile, when there is a $50 \%$ reduction in tariff on ASEAN-Canada FTA cooperation, it turns out that the real change of GDP earned by ASEAN member countries is not as big as full liberalization. The lowest countries in the real GDP change in both the first and second simulations, namely Singapore only $0.03 \%$, followed by Myanmar by $0.04 \%$ and Indonesia $0.06 \%$. Canada, however, does not take much of its domestic growth through real GDP, where there is only a $0.32 \%$ change when full liberalization and only $0.14 \%$ when a $50 \%$ tariff decline.

Table 4.6

\section{Impact of ASEAN-Canada FTA Cooperation on Real GDP (Persentae Change)}

\begin{tabular}{|c|c|c|c|c|c|c|}
\hline \multirow[t]{2}{*}{ State } & \multirow[t]{2}{*}{ Pre SIM1 } & \multirow[t]{2}{*}{ Pre SIM2 } & \multirow[t]{2}{*}{ Post SIM1 } & \multirow[t]{2}{*}{ Post SIM2 } & \multicolumn{2}{|c|}{$\begin{array}{l}\text { qgdp (\% } \\
\text { change) }\end{array}$} \\
\hline & & & & & SIM1 & SIM2 \\
\hline $\begin{array}{l}\text { Rest of } \\
\text { World }\end{array}$ & 67489696,00 & 67489696,00 & 67561256,00 & 67531544,00 & 0,11 & 0,06 \\
\hline Brunei & 16691,42 & 16691,42 & 16709,96 & 16704,31 & 0,11 & 0,08 \\
\hline Cambodia & 12829,55 & 12829,55 & 12947,89 & 12913 & 0,92 & 0,65 \\
\hline Indonesia & 845924,63 & 845924,63 & 846787,81 & 846441,25 & 0,10 & 0,06 \\
\hline Laos & & & & & 0,36 & 0,25 \\
\hline Mals & 289259,56 & 99.88 & 289259.5 & 29026 & 0,61 & 0,35 \\
\hline Philippines & 224095,25 & 224095,25 & 224339,00 & 224254,44 & 0,11 & 0,07 \\
\hline Singapore & 274064,72 & 274064,72 & 274226,72 & 274140,22 & 0,06 & 0,03 \\
\hline Thailand & 345669,84 & 345669,84 & 348064,34 & 347136,69 & 0,69 & 0,42 \\
\hline Vietnar & & & 137349,58 & 136673, & 1,34 & 0,84 \\
\hline & & & 56509,54 & 56501 & 0,05 & 0,04 \\
\hline Canada & 1778628,75 & 1778628,75 & 1784402,13 & 1781090,38 & 0,32 & 0,14 \\
\hline
\end{tabular}

Source: GTAP 9A data is processed, 2018

\section{Impact Analysis of ASEAN-Canada FTA Cooperation on Inflation of ASEAN Member Countries}

Overall the two simulations cause inflation which can be seen from the change in GDP deflator. The increasing GDP deflator shows an increasing producer price index. This will surely cause export prices to increase resulting in a decrease in exports and increased imports so that the trade balance becomes negative. Table 4.7 below shows the impact of ASEAN-Canada FTA cooperation on inflation, where the highest increase and decrease in GDP deflator occurred in SIM1 is a tariff reduction scenario of $100 \%$.
Table 4.7

Impact of ASEAN-Canada FTA on Inflation (Persentage Change)

\begin{tabular}{lrr}
\hline State & SIM1 & SIM2 \\
\hline Rest of World & $-0,85$ & $-0,40$ \\
Brunei & $-0,76$ & $-0,36$ \\
Cambodia & $-2,33$ & $-1,11$ \\
Indonesia & 2,96 & 1,10 \\
Laos & $-4,41$ & $-2,12$ \\
Malaysia & $-0,91$ & $-0,39$ \\
Philipina & $-1,99$ & $-1,04$ \\
Singapore & 1,62 & 0,74 \\
Thailand & 0,43 & 0,15 \\
Vietnam & 4,19 & 1,99 \\
Myanmar & $-0,08$ & $-0,11$ \\
Canada & $-2,07$ & $-1,05$ \\
\hline Source: GTAP
\end{tabular}

Source: GTAP 9A data is processed, 2018

The highest GDP deflator occurs in Vietnam in both SIM1 and SIM2, which is $4.19 \%$ and $1.99 \%$ respectively. Then followed by Indonesia of $2.96 \%$ in SIM1 and $1.10 \%$ in SIM1. For some ASEAN member countries, ASEAN-Canadian cooperation will benefit the country's GDP deflator but can also provide negative benefits for some other countries. Countries that benefit negatively on the GDP deflator are Brunei Darussalam, Cambodia, Laos, Malaysia, the Philippines, Myanmar and Canada. These countries will experience a greater decline in GDP deflator when applying full liberalization than the only $50 \%$ tariff reduction scheme.

\section{Impact Analysis of ASEAN-Canada FTA Cooperation on Trade Balance of ASEAN Member Countries}

The tariff reduction of both $100 \%$ and $50 \%$ in ASEAN-Canadian trade cooperation resulted in Brunei Darussalam, Cambodia, Laos, Malaysia, Thailand, Vietnam trade balance being negative or trade balance deficit. This indicates that the import value of these countries is much greater than the value of exports due to the increasingly open trading access and increased trade flows (see Table 


\section{INDANAZULFA QURROTA A'YUN \\ Asean-Canada Free Trade Agreement: Potential Economic For Asean Member Countries}

4.8). This condition will worsen if ASEANCanada trade cooperation does not provide incentives and long-term strategies for industry in increasing productivity through production or technology efficiency.

While for Indonesia, the Philippines, Singapore, Myanmar and Canada will increase their export activities and have a positive impact on their trade balance. This shows that there are sectors of the country that can take advantage of the ASEAN-Canada FTA cooperation by exporting. However, the circumstances of the surplus must remain in a precautionary position because given the benefits gained, of course, only occurs in sectors that have competitiveness.

Table 4.8

Impact of ASEAN-Canada FTA on Inflation (USD million)

\begin{tabular}{lrr}
\hline State & SIM1 & SIM2 \\
\hline Rest of World & 16401,22 & 8009,11 \\
Brunei & $-100,56$ & $-47,16$ \\
Cambodia & $-592,09$ & $-309,77$ \\
\hline Indonesia & 1088,14 & 449,83 \\
Laos & $-171,36$ & $-86,26$ \\
Malaysia & $-4917,22$ & $-2268,24$ \\
\hline Philippines & 622,18 & 288,72 \\
\hline Singapore & 1716,88 & 802,09 \\
Thailand & $-10939,14$ & $-5357,04$ \\
Vietnam & $-11462,91$ & $-5750,31$ \\
Myanmar & 205,17 & 98,08 \\
Canada & 8150,62 & 4171,09 \\
\hline Source: GTAPA
\end{tabular}

Source: GTAP 9A data is processed, 2018

This is certainly a motivation and challenge for ASEAN member countries in exploiting the opportunity of ASEAN-Kanda FTA cooperation in increasing trade flow through superior competitive products so as to increase surplus value of trade balance. One way to increase a country's exports is by increasing trade facilities which will encourage competition and innovation and lower costs.
Analysis of the Impact of ASEAN-Canada FTA Cooperation on the Investment of ASEAN Member Countries

Increased competition and innovation and reduced costs will make the attraction for investors. Empirically the existence of international trade and investment proved able to encourage the industrialization that can become the engine of economic growth. The investment conditions of ASEAN member countries in the ASEAN-Canada FTA scheme can be seen in Table 4.9 below.

Table 4.9

Impact of ASEAN-Canada FTA on Investment (Percentage Change)

\begin{tabular}{lrr}
\hline State & SIM1 & SIM2 \\
\hline Rest of World & 0,295 & 0,163 \\
Brunei & 2,255 & 1,119 \\
Cambodia & 6,643 & 3,508 \\
Indonesia & 1,888 & 0,796 \\
Laos & $-0,319$ & 0,001 \\
Malaysia & 2,344 & 1,249 \\
Philippines & 0,008 & $-0,003$ \\
Singapore & 1,492 & 0,697 \\
Thailand & 4,930 & 2,432 \\
Vietnam & 7,527 & 3,856 \\
Myanmar & 0,355 & 0,173 \\
Canada & $-0,298$ & $-0,116$ \\
\hline
\end{tabular}

Source: GTAP 9A data is processed, 2018

The existence of trade liberalization in the goods and services sector will certainly encourage businesses to adapt to the surrounding business environment. This will increase the attractiveness and improvement of the investment climate in the country. The highest investment increase in the full liberalization simulation was obtained by Vietnam which was $7.53 \%$, followed by Cambodia $6.64 \%$ and Thailand $4.93 \%$. While other ASEAN member countries that only get an increase of investment below $2 \%$ are Indonesia, Philippines, Singapore and Myanmar. Meanwhile, Laos and Canada have 


\section{JURNAL OPTIMUM, Volume 10, Nomor 1 Maret 2020}

decreased investment to $-0.32 \%$ and $-0.30 \%$. Laos despite not getting the highest investment increase, but still better than Canada where Laos will get an investment increase in simulation of $50 \%$ tariff reduction that is only $0,001 \%$. Then, for Canada, although the first and second schemes continue to decrease investment, Canada can still benefit from increased investment from the ASEAN-Canada FTA scheme with other simulations.

\section{CONCLUSION}

The simulation results of trade cooperation between ASEAN-Canada member countries using Computable General Equilibrium (CGE) indicates that the elimination of tariff of $100 \%$ (full liberalization) and $50 \%$ tariff reduction will impact on improving the welfare of all countries except Laos and Filippines. The highest increase in welfare is Indonesia, followed by Vietnam, Thailand and Malaysia. In addition to impacting welfare, the elimination of tariffs by $100 \%$ and a $50 \%$ reduction in tariff also affects the real GDP growth in all member countries of ASEAN and Canada although the percentage change is less than $1 \%$ except Vietnam, where Vietnam is a country with real GDP the highest at $1.34 \%$.

When viewed on the impact of inflation, almost all countries experience a decline seen from changes in GDP deflator. Several countries such as Indonesia, Singapore, Thailand and Vietnam benefit from higher GDP deflators in full liberalization schemes compared to 50\% tariff reduction schemes. Conversely, for some other countries such as Brunei Darussalam, Cambodia, Laos, Malaysia, Philippines, Myanmar and Canada actually get negative benefits and will be more losers when eventually held full liberalization. The highest GDP deflator occurred in Vietnam in both the first and second simulation of $4.19 \%$ and $1.99 \%$. While the lowest GDP deflator which experienced the highest decrease was Laos at $4.41 \%$ at the tariff decrease of $100 \%$ and by $2.12 \%$ in the decrease of $50 \%$ tariff.

A decrease in tariffs of $100 \%$ and $50 \%$ will result in the country's trade balance of Brunei Darussalam, Cambodia, Laos, Malaysia, Thailand and Vietnam experiencing deficit. This shows that the import value of these countries is much greater than exports due to the increasingly open trade access and increasing trade flows. While for Indonesia, the Philippines, Singapore, Myanmar and Canada will increase export activities that have a positive impact on the trade balance. The highest trade balance value in the full liberalization scheme between the ASEANCanada FTA is Canada which is USD 8150.62 million and the lowest is in Vietnam, which is USD 11462.91 million. This is certainly a challenge for the Vietnamese country if the ASEAN-Canada FTA is in place, because in the data mentioned earlier that Vietnam seems to be one country that has a positive trade balance and always increases every year.

The existence of trade liberalization in the goods and services sector will certainly encourage the occurrence of international trade and investment that can impact on industrialization and economic growth. In the ASEAN-Canada cooperation scheme, the highest investment increase in full liberalization simulation was obtained by Vietnam at $7.53 \%$, followed by Cambodia $6.64 \%$ and Thailand $4.93 \%$. Meanwhile, Laos and Canada have decreased investment to $0.32 \%$ and $-0.30 \%$. For Canada, although in the first and second schemes still decreased investment, Canada can still benefit from increased investment from the ASEANCanada FTA scheme with other simulations.

\section{REFERENCES}

Baldwin, Robert E. (2003). Openness and Growth: What's The Empirical Relationship?. National Bureau of 
INDANAZULFA QURROTA A'YUN

\section{Asean-Canada Free Trade Agreement: Potential Economic For Asean Member Countries}

Economic Research, Working Paper No. 9578.

Barichello, R.R. and Yap, J.T. (2010). Three Year ASEAN-Canada Policy Research Programme: A Proposal. Institute of Southeast Asian Studies.

Bowen, Harry, Hollander, Abraham, et al. (2001). Applied International trade Analysis. University of Michigan Press.

CABC. (2017). The ASEAN Advantage: Exploring Canada's Trade Potential. Canada-ASEAN Business Council, Boncouver.

CABC. (2013). Survey of Canadian Business in ASEAN. Canada-ASEAN Business Council, Voncouver.

Caliendo, Lorenzo and Parro, Fernando. (2014). Estimates of the Trade and Welfare Effects of NAFTA. The Review of Economic Studies Advance Access. Oxford University Press.

Halwani, RH. (2005). Ekonomi Internasional dan Globalisasi Ekonomi. Ghalia Indonesia, Bogor.

Hertel, Thomas W and Martin, Will. (2001). Second-best Considerations in Multilteral Trade Liberalization. Review of International Economics. Vol. 9, pp. 215-232.

Jadoon, Atif Khan, et al. (2015). Trade liberalization, Human Capital, and Eeconomic Growth: Empirical Evidence from Selected Asian Countries. Pakistan Economic and Social Review. Vol. 53 No. 1, pp. 113132.

Krugman, P. (1991). Geography and Trade. MIT Press Books, Cambridge

Lloyd, Peter, and Maclaren, Donald. (2004). Gains and Losses from Regional Trading Arrangements: A Survey. Economic Record. Vol. 80, pp. 445467.

Lloyd, Peter. (2010). Global Economic Integration. Pacific Economic Review. Vol. 15, pp. 71-86.
Okabe, M and Urata, S. (2004). The Impact of AFTA on Intra-AFTA Trade. Journal of Asian Economics. Vol. 35, pp. 1231.

Oktaviani, R., Tanti, N., \& Widyastutik. (2008). Pola dan Dinamika Perdagangan Indonesia Timur Tengah dan Indonesia-Meksiko: Kajian Awal Analisis Dampak FTA. Direktorat Jenderal Pendidikan Tinggi, Departemen Pendidikan Nasional.

Sachithra, K. (2000). Comparative Advantage in International Trade: A Study Based On Leading Exports in Sri Lanka. Journal of India Economy and Business. Vol. 1, pp. 1-35.

Salvatore, Dominick. (2012). International Economics, $11^{\text {th }}$ Edition. AddisonWesley Publishing Co., New York.

Siriwardana, Mahinda. (2015). Australia's new Free Trade Agreements with Japan and South Korea: Potential Economic and Environmental Impacts. Journal of Economic Integration. Vol. 30, pp. 616-643.

Trade Map. (2018). Trade Balance of ASEAN Member Countries and Canada. www.comtade.un.org., accessed on May 27, 2018 at 11.00 am

Winham, Gilbert R. (2003). The World Trade Organisation: Institution-Building in the Multilateral Trade System. The World Economy. Vol. 21.

Woo, Y.P. (2005). Canada-ASEAN Economic Relations: Assessment and Prospects. Asia Pacific Foundation of Canada.

Worldbank Data. (2018). Population of ASEAN Member Countries and Canada. www.data.worldbank.org., accessed on May 27, 2018 at $3.00 \mathrm{pm}$

Wyatt, A and Walter. (1996). Adam Smith and the liberal tradition in international relations. Review of International Studies. Vol 22, pp. 5-28.

Zhou, S. et al. (2010). Study on the Impacts of China-ASEAN Free Trade Area Based on the Simulation of GTAP 
JURNAL OPTIMUM, Volume 10, Nomor 1 Maret 2020

Model. GTAP Conference Paper.

Purdue University. 